\title{
THE ECONOMIC DYNAMICS OF RIVER BASIN DEVELOPMENT
}

\author{
WIILIAM E. Fozz*
}

It would be comforting if, in an article such as this, one could promise the elucidation of a method or a model for predicting the nature, the chronology, and the extent of the economic expansion likely to occur if the development of a river basin is undertaken. The writer must, however, at the outset, disclaim and discourage any such hope. Indeed, much the better part of valor would have been completely to forego exploration of this nebulous area; but so many of the benefits ascribed to river basin development depend upon its expected economic consequences that these matters could not conscientiously be ignored. Accordingly, an attempt will be made here to delineate-albeit roughly-the economic dynamics of river basin development.

Despite the evolution of a theoretical framework that would facilitate analysis, ${ }^{1}$ economists have devoted scant attention to the role played by natural resources in the inducement of economic expansion. ${ }^{2}$ As has been observed, "There is no received theory of economic development." ${ }^{3}$ This is particularly surprising in the light of analogous developments in economics and allied sciences. Thus, the theory of interest and capital accumulation has been minutely explored; ${ }^{4}$ technology and its influence on economic dynamics has likewise carefully been studied; ${ }^{5}$ and labor theory and the effect of wages on economic expansion have also rigorously been analyzed. ${ }^{6}$ In a similar vein, Turner's emphasis on the frontier and its significance to the growth of

* B.S. 1927, Evansville College; M.S. 1933, Ph.D. 1935, University of Illinois. Professor and Chairman of Department of Agricultural Economics, University of Idaho. Author, AN ANalysis of ThE INcome StRUCtuRE OF IDAHo (I952).

${ }^{1}$ See Folz, The Theory of the Relation of Resources Development to Economic Development, in' Water Resources and Economic Development of THE West I (1953).

${ }^{3}$ Henry George, Progress and Poverty (1879) was posited on the thesis that land and resources were the most significant factors influencing economic development. The effect of this book upon economists, however, was to induce them to deny that land was in any way different from other factors of production. John Bates Clark, for example, applied the law of diminishing returns, which had previously been considered the exclusive property of land rent, to other factors of production, and although he recognized the monopoly attribute of land, he maintained that it was of little importance. See 2 Joseph Dorfman, The Economic Mind in American Civilization 198 (1949). See also Alvin S. Johnson, Rent in Modern Economic Theory (1902); J. J. Davenport, The Economics of Enterprise r78-208 (1913). After this charge against the foundations of the theory of rent, later economists sought to re-establish the older theory. See, e.g., Alfred Marshall, Principles of Economics 415-23 (1930). But none seemed eager to venture into the controversy to the point of overemphasizing the importance of land. See Richard T. Ely and George S. Mefriwein, Land Economics r-it2 (1940); Roland R. Renne, Land Economics 3-100 (1947).

${ }^{3}$ Schultz, The Economic Development of Our Western Interior, 35 J. FarM. Econ. 707 (1953).

- See Eugen v. Bohm-Bawerk, Positive Theory of Capital (W. Smart transl. 1890); Gustav Casser, The Nature and Necessity of Interest (I903); Irving Fisher, The Theory of Interest (1930).

"See Joseph Schumpeter, The Theory of Economic Development' (i934).

'Sec F. W. Taussig, Wages and Capital (1896), and Outlines of a Theory of Wages (igio); Lionel Robiins, Wages (1925); J. R. Hicks, The Theory of Wages (r932). 
democracy and economic expansion ${ }^{7}$ has occupied the minds of historians and political scientists for over a generation. ${ }^{8}$ And the new science of geography, too, has been finding fresh bases for emphasizing resources as the cause of economic expansion. ${ }^{9}$

It is beyond the scope of this article to inquire into the reasons for economists' failure to emphasize resources as an inducement to economic expansion. Perhaps they have felt that all that can be said either is obvious or has already been said. Perhaps they also have reasoned and wished to stress that resources are assets that a country either has or does not have and about which it can do nothing, while technology and capital, for example, are elements of wealth that can be increased to the advantage of even a country with limited resources. Nor is it the writer's intention to criticize economists for not elaborating this area more intensively. These introductory remarks rather purpose to underline the fact that when an economist seeks to explore the effects of resources on economic expansion, he has a comparatively limited body of theory upon which to draw. He must, instead, develop his own theories with the tools available, which, for the most part, were forged to fashion somewhat different products.

\section{I}

\section{The Inducement of Economic Expansion}

An inquiry into the influence of river basin development on economic expansion can, perhaps, best be initiated by a determination of the types of resources that are likely to be created or enhanced by such development and then an evaluation of these resources as dynamic economic prime movers.

Most river basin development provides water to irrigate newly opened lands, to supplement existing water supplies available to already developed lands, and for domestic and industrial uses, health, and sanitation. Storage dams constructed to furnish these utilities may also further provide for the regulation of the water level for navigational and flood-control purposes, for the generation of electricity, and for recreational facilities in the artificial bodies of water that are frequently created.

In evaluating these products of river basin development as factors inducing economic expansion, it is necessary first more precisely to define the area of analysis.

\footnotetext{
${ }^{7}$ Frederick J. Turner, The Significance of the Frontier in American History ig7 el seg. (1893).

${ }^{8}$ See, e.g., Frederic Logan Paxson, The Last american Frontier (igio); B. H. Hubbard, A History of the Public Land Policies (igro); F. A. Ogg, The Old Northwest (1921); J. D. Hicks, The Populist Revolt (I93I); Theodore Saloutos and J. D. Hicks, Agricultural. Discontent in the MIDDLE WEST (I95Y). For further discussion of Turner's infuence on history, see Wright, Political Institutions and the Frontier, Craven, The Advance of Civilization into the Middle West in the Period of Settlement, and Hicks, The Development of Civilization in the Middle West, 1860-1890, in DixoN Ryan Fox (Ed.), Sources of Culture in the Middle West: Backgrounds versus Frontier 15, 39, and 73 (1935).

${ }^{\circ}$ See, e.g., American Geographicat Society, New England's Prospect (Spccial Pub. No. 16, 1933); ERICH ZimMermann, World Resources and Industries (rev. cd. 1951); Baker, The lncreasing Importance of the Physical Conditions in Determining the Utilization of Land for Agricultural and Forest Production in the United States, II ANN. Ass's Am. Geographers 17 (1921); Zierer, An Ephemcral Type of Land Occupancy, 31 id. at 125 (1936).
} 
Water resources may become depleted in a rapidly growing area; like land in an area where population is growing rapidly, water may become a scarce resource. When scarce, there is competition for its uses, and its marginal value productivity increases. New sources of water supply are then sought, and if the supply is increased, it is usually available only at greatly increased costs. If additional water supplies are not made available, water may become a limiting factor to economic expansion-and such situations are increasing. Thus, for example, certain parts of California are already facing an arrestment of growth owing to water shortage; and the future growth of the populous industrial areas in the East will largely depend on their ability to restrict those uses of water the marginal utility of which is lower than that of urban development uses. Problems of this type are unquestionably significant, but they arise only where growth is already occurring. The problems are quite different in areas where growth is either slow or arrested, and where river basin development may be expected to afford some stimulation. It is with this latter type of situation that this article will concern itself.

When economic expansion is considered, distinctions must also be drawn between the growth of primary industries, those industries that are resource-oriented, and the superstructure of industries, which, in turn, are induced by the primary industries. Although this article will concern itself with the entire growth factor, attention in this part will be focused exclusively on the location of primary industries.

Finally, further to clarify the definition of this study, other relevant factors will be regarded as remaining constant. Thus, climatic factors neither so severe nor so attractive as unduly to retard or stimulate growth will be assumed, nor institutional factors concerning laws and customs significantly different from those in the rest of the country. Similarly, the population will be assumed to be possessed of the same ability as the population in other regions.

Within this framework, an analysis of the probable effect of supplying the combination of utilities usually associated with river basin development may proceed.

Irrigated farms for settlement by homesteaders are probably the most efficient of the products of river basin development in inducing economic expansion. Land for farms is always in great demand. This was the case even when a vast frontier existed in this country and when there was no apparent limit to land available for farms; and it is probably even more so today, when available new farm land is scarce. This seems paradoxical when farm surpluses are faced in every commodity and the cost of settlement, in terms of labor, money, and privation, is so great. Indeed, most settlers today can, at best, hope to make an adequate living only after eight to ten years of hard work and subnormal living conditions; and the statement is frequently heard that it takes three failures to make one success on an irrigated farm. ${ }^{10}$

\footnotetext{
${ }^{20}$ Based on informal interviews with surviving first settlers in the Twin Falls Project, Twin Falls, Idaho, conducted by the writer in preparation for a study of reclamation in Idaho. The most complete study of settler experience, however, is being made in the developing Columbia Basin Project. In Washington Agricultural Experiment Station Institute of Agricultural Sciences, The Columbia Basin Settler: A Study of Soctal and Economic Resources in New Land Settlement (Bulletin No.
} 
With such a prospect confronting them, then, why do settlers seek these farms and consider themselves fortunate if they win one in a drawing?

Probably the most important single reason underlying this demand for farm land is the widespread willingness of individuals to accept a lower income in farming than they would in any other economic pursuit, owing, perhaps, to the supposed compensatory advantages of farming as a way of life. On newly developed lands, there is also the long-run prospect of significant capital gains. Throughout our history, land values have invariably reached a new peak each generation. The anticipation of such possible appreciation of one's capital assets does not exist in many other occupations open to the average citizen. And finally, the settlement of new lands does not require more capital than individuals with ordinary means can amass. This greatly broadens the market for new lands, for as the economies of scale of most businesses operate to increase their initial capital requirements, fewer opportunities exist in such businesses for individuals of moderate means.

River basin development which provides for new lands for settlement, therefore, will be sure to attract homesteaders into the project area, even if there are serious obstacles to overcome in bringing new farms into production and marketing their products. Will other resources made available by river basin development, however, be equally dynamic in inducing economic expansion?

Water power is an energy resource-in fact, the most important single resource in the electrometallurgical and electrochemical industries. But in other industries, although electricity may be substituted for other energy resources, it is not so important a factor as alone to determine the location of plant sites-in fact, expenditures on electricity are usually so small in most industries as to constitute an almost negligible factor as compared with labor or markets in this regard. Moreover, when unused electric power capacity abounds in other sections of the country, there is little likelihood that additional capacity will be installed in newly developed areas. Accordingly, cheap electric energy cannot be expected to attract industries, even of the electroprocess variety, during periods of less than full employment.

Most electroprocess industries also require large capital investments, thus limiting entry into the field-and the consequent industrial demand for electric power-to well-established businesses with large capital assets and experience. Furthermore, even if a new enterprise could surmount this initial difficulty, it still would face the problem of monopoly or, at best, oligopoly. For, although the economics of location might designate a new area with vast quantities of cheap electricity as the logical

566,1956 ), an analysis was made of the economic position of new settlers. This project has been accompanied by less privation on the part of settlers than occurred in earlier developments. Id. at 32. Neverthe. less in 1954, one-third of the settlers had annual incomes of less than $\$ 2000$. Id. at 25 . In an unpublished report prepared by one of the authors of this study, it further appears that those who had settled on the land prior to I948 had annual net incomes of $\$ 5700-\$ 6900$; those who had settled I952-53 had annual net incomes, depending on the size of their operations, of \$170-\$1r13; but those who had settled in 1955 had negative annual net incomes averaging \$1000. B. D. Parish, Report on Settrer Progress: Co. lumibia Basin Project iz (1956). 
place to build new facilities, oligopolists with plants in other areas might adopt or threaten to adopt price policies designed to discourage such undertakings.

Nor should undue reliance be placed on the recent successful experiences that have accompanied basin development in the Pacific Northwest and in the Tennessee River Valley. Although new industries did, in fact, develop in those areas in the face of competition with older established industrial regions, this phenomenon coincided with World War II. In the Pacific Northwest, in particular, most of the basic plants were built, in the first instance, through public investment in war plants, and most of the industries which use the products of these plants have also been governmentfinanced and sustained. ${ }^{11}$ Possibly such growth might have occurred had not the war supervened, but such a conclusion would be highly suspect.

There is, of course, some possibility that industrial location can be induced in new areas by promotional rates for electricity. If the power company would so adjust electricity rates as to persuade established industries to write off their investments in plants in older areas and to relocate, industrial development based upon electricity might be accelerated in the new areas. It is doubtful, however, that promotional rates of such magnitude could be established, especially by a governmental agency, without inciting political repercussions from the adversely affected areas-those losing the industries. ${ }^{12}$

Thus, although possibly significant in the electroprocess fields, cheap and abundant electricity would seem somewhat less certain to induce location in an area than would new agricultural land. But if it is doubtful that water power is an autonomous force in inducing economic expansion, the other products of river basin development are even less so. Water transportation along the inland rivers, for example, has long ceased to be of prime importance in locating industries. The points of origin and of distribution are too limited to encourage much trade, and where transshipment by railroads or trucks is also involved, the purported economies are soon lost. The cost of flood control or the possibility of floods, too, may be a deterrent to economic expansion, but flood control in itself cannot be a significant prime mover in economic expansion.

As national income has risen and leisure become more widely enjoyed, recreation has come to be considered a resource of increasing importance. It is difficult, however, to place a market value on a resource, such as this, for which there are no direct sales. Economically, this type of resource can be evaluated only indirectly-through

${ }^{11}$ See Wirltam E. Folz, AN ANalysis of the Income Structure of Idaho gi (1952).

${ }^{13}$ Protests were made by business groups against the establishment of promotional rates by the TVA designed to lure northern industry to the South. The protests were so vigorous, in fact, that President Roosevelt was impelled to write a letter to Representative Thom, of Ohio, denying the charge. President Rooscvelt stated in the letter:

"This is in reply to your letter of February twenty-first in which you call to my attention the report that representatives of the TVA are endeavoring to induce Ohio manufacturers to move to the Tennessee Valley in order to secure the benefits of cheap power."

"It is a definite policy of the Tennessee Valley authority that no such action be taken in respect to Ohio or any other region." 4 The Public Papers and Addresses of Frankiln D. Roosevert 106 (r935). 
the sale of goods and services required to utilize it-and economic theory and price theory have, unfortunately, provided little to guide such evaluations. Economists themselves, for the most part, have avoided the problem, and, consequently, individuals with little or no economic training have propounded solutions, albeit with little understanding of the economic issues involved.

In most areas where river basin development is contemplated, fish and wildlife abound. An additional lake or reservoir, therefore, will add little to the total value of recreation. Of course, it may draw sportsmen from other rivers and streams; it may even, for a time, encourage additional utilization of the resource by individuals from nearby communities. But most evaluations of the particular resource will, in fact, probably overshoot the mark, because what should be measured is the marginal value product, whereas all that can be measured is the average value. To be more specific, it is not economically justifiable to measure the value of an artificial lake created by a dam on a river by the amount of fishing, boating, cabins, hotels, etc., to be found there. What should be measured, instead, is the amount of additional recreational expenditure attributable to this one additional lake. Or, to state the problem differently, if this one lake did not exist, how much less would be spent on outdoor recreation? It is not logical to assume that if this one lake did not exist, all the individuals who fish or have cabins there would neither fish nor have lake cabins at all; most of them would likely utilize the next most accessible resort. If only the incremental value thus described could be measured, therefore, the contribution to recreation by any one river basin development would, in most cases, probably be quite small.

On the other hand, it is not fair to assume that the demand for recreation does not respond to an impact effect. If only a few recreational sites are available, there may be little utilization of them; but when many are made available, more people may become conscious of them, and the demand for this type of resource may, for a time, respond in a geometrical ratio to the quantity available. Even if we grant this hypothesis, however, there still remains a serious problem of how to measure the impact of any one additional facility on the entire demand.

The implications, nevertheless, clearly are that recreational facilities made available by river basin development also have a low growth-inducing power. One would be hard put to indicate a single instance where significant economic expansion stemmed from the creation of recreational facilities of the type associated with river basin development. While such services may have significant value if other dynamic factors exist, in and of themselves, they have little developmental value.

\section{II}

\section{The Extent of Economic Expansion}

In the foregoing part, the following conclusions have been suggested: ( $\mathrm{I}$ ) Irrigated agriculture is probably the most certain of the products of river basin development to induce economic expansion. (2) Electric power rates quite high as a prime 
mover to economic expansion, but it is not as certain as irrigated agriculture to bring it about. (3) Other by-products of river basin development, such as navigation, flood control, and recreation, have only negligible potential for inducing economic expansion.

To encourage industries which utilize the resources made available by river basin development, however, is only the first step in the economic expansion of an area. Industries which are resource-oriented in turn induce the location of other industries. Thus, some industries will locate in the area because they further process the products of the primary industries; others because of the growing market based upon the incomes of individuals working in the primary and secondary industries; and still others will be purely service activities, entirely population-oriented. A mature economy is one that derives most of its income from activities other than primary or secondary industries-i.e., from the manufacture of finished products, trade, finance, and services. Once the growth of a region is initiated by the location therein of farming, electrometallurgical and electrochemical plants, and other industries utilizing the raw materials of the area, then, how far will it proceed towards a mature economy?

This question is difficult to answer. There have probably been no instances in which development of a region has not been spurred by such exogenous influences as wars, public investments, discovery of valuable mineral deposits, or other equally powerful forces. Attempts have been made, however, to determine how an economy will develop by analyzing the location of primary industries and the income derived from other sources.

Two general types of empirical studies have been made. First, and by far the more impressive when viewed from the standpoint of its scientific conception, is the application of the Leontief input-output analysis to regional growth. The second method, which, although much less impressive and imaginative, still has its advantages, is the case-study approach, in which areas somewhat protected from exogenous influences are selected and the structure of their economies analyzed after a period of growth has occurred. It will not be possible here to study these two approaches in detail, but a brief summary of their methods and results will facilitate evaluation of the growth factor as it affects river basin development.

The Leontief method is based upon the general equilibrium theory developed by Walras about eighty years ago. ${ }^{13}$ Its basic hypothesis is that all elements of an economy are interdependent, each factor being determined by all the other factors, and, in turn, affecting every other factor. For every input, there is a corresponding output; and for every output, there is a corresponding input. Thus, if a complete inventory could be taken of the entire economy for one period (say a year, as in the census years), all economic activities of a country could be classified as inputs and as corresponding outputs, every activity on the input side being measurable as a

\footnotetext{
${ }^{13}$ Leon Walras, Elements of Pure Economics or the Theory of Social Wealth lesson 12 (Jaffe
} transl. 1954). 
service or a utility on the output side. By solving the equations simultaneously, the individual coefficients of each input, as it is affected by and as it, in turn, affects every output, could be determined; these would be technical coefficients, in Leontief's terminology. Once these technical coefficients were established, the impact of any change in any of the input factors on the output of the entire economy could be determined.

Leontief applied his analysis to the American economy for the years 1919, 1929, and I939. ${ }^{14}$ Those were years in which census data were available to give the closest approximation to statistics for an entire balanced economy. For each of these census years, coefficients were computed, based upon the input-output relationship. By taking the r939 coefficients and applying them to I929 and Igrg total demand, the output of the various sectors of the economy was estimated, and these estimates were compared with the actual output. The results showed surprisingly small standard errors in prediction, which would appear to indicate that the technical coefficients are fairly fixed over time. ${ }^{15}$

Essentially the same type of analysis has been applied to regional economies to study changes in their structures. ${ }^{16}$ This method has much to commend it. The development of the matrix itself, however, demands that the economist analyze all the interrelations of industries in the region, as well as all factors influencing location of industry and the characteristics of the industries themselves-e.g., whether they tend to be national industries (selling in national markets), regional industries (selling only in regional markets), or subregional industries (selling only in local markets). A complete input-output analysis would also include all factors entering into the regional balance of payments. Further, once the basic data for the matrix were secured, their organization for the regional model would require additional information, such as the effect of interregional competition on the development of new industries in the area, the response of demand to unusual supply, and a detailed analysis of comparative advantage. Finally, the technical coefficients derived from the economy as a whole would provide as good a basis for determining the distribution of the markets among regions as could likely be derived from any scientific analysis of this type.

There is a sound basis, then, for applying the Leontief model to the analysis of the impact of river basin development on regional growth; but, for several reasons, such a venture has never been undertaken. Before the technique can be used, as noted above, empirical data of such exactness are required that the task of compiling them would be almost prohibitive. Moreover, many of the judgments that would have to be made in supplying data for the matrix would have to be based upon untested hypotheses. For example, how does demand for the various commodities

is Wassity W. Leontief, The Structure of the AMerican Economy (2d cd. 1951).

${ }^{15} 1 d$. at $2 \times 7-18$.

${ }^{20}$ Wassizy W. Leontief and Others, Studies in the Structure of the American Economy cc. 4, 5 (1953). See also Isard, Location Theory and Trade Theory Short-ran Analysis, 68 Q. J. Econ. 305 (1954). 
distribute itself among the regions? Are the various regions equally dependent upon income earned within the region, or do some regions derive a greater percentage of their incomes from investment outside the region? To what extent will competition from well-established firms in one region counteract the comparative advantage of other regions? These and many other similar questions must be answered before a complete and accurate analysis of the dynamics of regional development can be described by the Leontief model. Furthermore, once the model were constructed, its conclusions would still be only tentative. Nevertheless, some of the river basin studies have required extremely large staffs, and literally small fortunes have been spent on them. Had the time and money been devoted, instead, to the development of a detailed and logical model of the Leontief type, better results might well have been achieved. There now is, however, no information developed by use of the Leontief model to aid in evaluating the effects of river basin development.

The second method that has been employed, namely, the case-study method, has provided some helpful information, but it leaves unanswered many questions regarding the dynamics of regional development. The most detailed study of this nature was made in connection with the Columbia Basin Project, where, about the time construction commenced, a group of investigators was assigned the task of appraising the economic effects of the development, of attempting to assess the full economic impact of the reclamation program. ${ }^{\mathbf{1 7}}$ The method used was to determine the cropping pattern by analyzing the soil characteristics, it being assumed that sufficient processing plants and marketing services would develop to handle the products of the soil. Estimates of population growth in the area were based upon independent calculations. The problem of marketing the products of the area was viewed as one of handling the surplus over and above those consumed by the population. This procedure was about as good as could be devised with the tools available at the time, but limitations were imposed on the studies by lack of knowledge of the extent of development apart from agriculture, which was the most dynamic factor in determining both income and population growth in the area. ${ }^{18}$

During the period following the onset of the depression in 1929 , interest in new irrigation projects waned as it became apparent that it was not agricultural, but rather more nonagricultural investment opportunities that were needed. Accordingly, in justifying its new projects, the Bureau of Reclamation and others placed much emphasis on off-site nonagricultural developments, which were usually classified as secondary benefits. No effective way had yet been devised to gauge these benefits, however, and to afford some basis for measurement, the Bureau of Reclamation insti-

\footnotetext{
${ }^{17}$ John A. Guthrie, Wendelt T. Calmoun, and Marion Clawson, Markets and New Lands (1942).

18 "Forecasts of population for the region indicate an increase of around 25 per cent within the next three decades. Industrial and other developments during this war may alter the situation to some extent, but the general trend is reasonably clear. In the study here reported, it has been assumed that the regional consumption of agricultural products would increase in direct proportion to such growth in population." Id. at vii.
} 
tuted a series of case studies of developed projects to ascertain the amount of income derived directly from the projects and the amount of income derived from industries and services induced by the projects.

The first of these studies was undertaken by M. E. Marts in the Payette area in Idaho. ${ }^{19}$ This area was selected because it was a well-established project, and, consequently, had experienced ample opportunity for full development at the time the study was initiated. The Payette area would have experienced no agricultural development whatever had water not been made available, as there were no other natural resources to be exploited. So, the entire growth of the area was unquestionably attributable to the project. The results of the study showed that for every dollar of income derived from agriculture, an additional $\$ 1.27$ of nonagricultural income was generated in the immediate project area. ${ }^{20}$

Other studies of this type. followed. In November 195I, the Bureau of Reclamation published a study of the Carlsbad Project, attempting to ascertain the amount of income derived from sources other than agriculture in that area. ${ }^{21}$ The author of this study, however, used gross value figures instead of net income figures as in the Marts study; consequently, the results of the two studies are not directly comparable. He also aggregated the values for the years r907 through I950, and he concludes: "The sum of the income to the farm population, the local urban and the national trade activities due to the project is about $\$ 306,622,000$, or 607 per cent of the value of crops produced on the project during the 44 year period.22 While this conclusion is quite impressive, it has little value for the purpose of evaluating river basin development.

A month after the appearance of the Carlsbad study, a report on the Yuma and Gila Projects in Arizona and California appeared. ${ }^{23}$ This report followed the method used by Marts in the Payette study; it concluded that in the Yuma and Gila trading area, for every dollar of net income ${ }^{24}$

... accruing to the basic agricultural industry of the area in the form of farm income and wages to farm labor, an additional net income of $\$ 1.74$, indirectly attributable to agriculture, accrues to local supporting business, service establishments and their employees.

In February 1952, a study of the accomplishments of irrigation in Weld County, Colorado, was published. ${ }^{25}$ This study showed the relationship of nonagricultural to agricultural income to be almost exactly the same as that found by Marts in the Payette area-I29 per cent. ${ }^{26}$

${ }^{20}$ M. E. Marts, An Experiagent in the Measurement of the Indirect Benepits of IrrigationPAXetTe, IDaho (I950).

${ }^{20} \mathrm{Id}$. at 5 .

${ }^{21}$ U. S. Buneau of Reclamation, Dep't of the Interior, an Evaluation op the EFpect on the Carisbad Irrigation Project on the Local and National Economy (195i).

22 Id. at 20.

${ }^{33}$ U. S. Bureav of Reclancation, Dep't of the INTERtor, Evaluation of Locat Irrigation Accomplishaments, Yuma and Gila Projects' Trade Area Arizona-California (195i).

${ }^{34} I d$. at $\mathrm{x}$.

${ }^{25}$ U. S. Buread of Reclamation, Dep't of the INTERIor, Accomplishments of Reclamation WeLd County, Colorado (r952).

${ }^{26}$ Id. at 30 . 
Two other studies were made for the purpose of determining the amount of indirect income generated on irrigation projects. A study of the Klamath Project followed a procedure not comparable to the others, and, consequently, no conclusion of value here can be inferred from it. ${ }^{27}$ A study of the Newlands Project, however, followed the pattern set by the Payette and Yuma-Gila income studies, and the results were quite similar, showing an indirect income in the trading area equal to I20 per cent of the income derived directly from agriculture. ${ }^{28}$

From the studies made of irrigation developments, therefore, it would seem reasonable to assume that once agricultural land is brought under cultivation, processing industries, retail trade, community facilities, and service industries will develop and give rise to about I25 per cent more income than that derived from agriculture itself. But while these studies represent a start in the direction of measuring the dynamics of regional development, they fall far short of providing the basis for a complete analysis. Nevertheless, several points are clear: Agricultural developments, of themselves, do not generate great economic expansion; the manufacturing facilities that emerge to process agricultural products do not provide large payrolls; development of an area based upon agriculture does not proceed far enough to attract market-oriented industries; and, consequently, economic growth stops short of maturity. If great economic expansion is to occur, therefore, forces other than agriculture must generate it. Can river basin development supply these other forces?

Probably the most complete study of industrial development of a region was made by Edwin J. Cohn, Jr., who attempted to analyze the structure of economic growth in the Pacific Northwest to ascertain whether development would proceed to a point where high industrialization based upon electric power would occur. ${ }^{2 \theta}$ In general, his conclusions were somewhat unsanguine. He recognized, of course, that industries of the electroprocess variety, which require vast quantities of cheap electricity to operate, did locate in the Pacific Northwest, although the extent to which this location was influenced by the war and by heavy public investments was not assessed. He observed, however, that the most striking failure of the Pacific Northwest to date has been its inability to develop industries which process the new materials provided by these primary industries. For example, according to Cohn, the Pacific Northwest is unfavorably located with respect to markets to develop aluminumprocessing industries. Such enterprises require large capital investments, their power consumption is small, and they must locate close to the market and subcontracting industries. Freight rates encourage the shipment of raw materials but discourage the shipment of finished products and products of supporting industries, and the aluminum industry itself follows the practice of absorbing freight on new competing market-oriented industries. The rolling plant at Trentwood, in the suburbs of

\footnotetext{
${ }^{27}$ U. S. BuREaU of Reclamation, Dep'T OF THE INTERToR, Reclamation Accomplishments, KLAMath Project Oregon-California (1952).

${ }^{38}$ U. S. Bureau of Reclamation, Dep't of the INterior, Evaluation of Irrigation Accomplishments Newlands Project Trade Area Nevada i2 (1952).

${ }^{20}$ Edwin T. Cohn, JR., Industry in the Pachic Northwest and the Location Theory (1954).
} 
Spokane, Washington; would seem to refute this analysis, but had the plant not been placed on the market at a bargain by the Defense Plants Corporation, it would probably not be in operation today.

Even industries which accidentally located in the Pacific Northwest, such as the Boeing Aircraft Co., the Northwest Iron Fireman Co., Brown Industries, and Pacific Car and Foundry, have found, as they seek national markets, that they are not strategically located. All these companies, accordingly, have either established branches in other sections of the country or have contemplated doing so. The prediction, made by proponents of power development in the Pacific Northwest, that large numbers of secondary industries would locate there because of the existence of cheap metals, thus, have not materialized. The industrial development that has occurred has been confined to the primary industries and to industries dependent upon local markets. Dr. Cohn summarizes his conclusions as follows: ${ }^{30}$

The development of hydro-electric resources to produce cheap power should not of itself be expected to attract industry except for that very limited class of manufacturing, the electro-process industries, which consume such immense quantities of energy that they are forced to locate with primary regard to the availability of plentiful cheap power. The employment such enterprises create is small, however, and the related industries which follow them are few. On the other hand, in regions where the lack of a firm energy base retards industrial development, the harnessing of hydro-electric or other power sources can contribute substantially to industrialization. Providing power, however, only removes an obstacle, it does not introduce a positive industrializing force.

If we accept these conclusions as definitive, the question raised at the beginning of this part seems to be answered. Except for the rather modest economic growth attributable to irrigation, river basin development cannot be expected to trigger any momentous expansion. If industrialization takes root for other reasons and electric energy is a limiting factor, such development may permit greater expansion to occur than would otherwise be possible. The pattern of economic expansion to be expected in a region where river basin development has been undertaken, thus, is the location of primary industries (i.e., agriculture, electroprocess, and somewhat more intensive utilization of natural resources already there) and a growth of trade, finance, construction, and community services-and even the latter type of activity will be somewhat restricted because of the lack of a good base for support.

There is a danger, however, that this conclusion about location theory may prove too much. In the last analysis, if industrialization depends upon mass markets, and mass markets depend upon population and its purchasing power, and population depends upon economic opportunities, and economic opportunities, in their turn, depend upon industrialization, we find ourselves involved in circular reasoning. The conclusion we reach is that industrialization depends upon industrialization, which negates economic history. We know that industrialization came to the eastern coast of the United States in the face of many of the locational limitations faced by the

${ }^{30}$ Id. at 179 . 
Pacific Northwest today. Later it moved to the Midwest and to the South, in competition with established industries in the East. The same types of locational obstacles, it would seem, could be overcome in locating industry in the Pacific Northwest. Dr. Cohn does not deny this. He concludes only that hydroelectric power, in itself, is not a strong enough force to bring this about; there must be some other outside factors to induce industrialization.

What, then, are the other forces that will induce industrialization? Are they likely to occur where river basin development is undertaken?

Probably the most important single component of economic expansion, apart from the physical resources themselves, is population. This factor has not been considered so far because population cannot be treated apart from the economic opportunities which attract it. If river basin development increases economic opportunities, it will attract population; and population, in its turn, will attract industry. A large population providing cheap labor, for example, if combined with the existence of other raw materials, may draw industry away from older established regions, even in the face of adverse freight differentials. Similarly, a population with a high purchasing power can attract market-oriented industries; and if such population is highly concentrated and if its income is large enough, industrialization will occur even with resources that are otherwise somewhat limited. This seems to have been the case in Florida, California, and the Southwest. But population cannot grow in a vacuum. There must exist either economic opportunities to attract population in the first instance, or the population must have income from sources outside the region. In most cases of economic expansion, there exists a little of both.

Apart from industrialization, the dependent variable, the only economic opportunities a region affords are agriculture and the exploitation of resources. The exploitation of valuable mineral resources, however, such as oil, the precious metals, and rich base metal ores, usually does not result in a high concentration of population. In most industrialized regions today, industrialization rather originated with agriculture. The small diversified farms of the East and the Midwest brought population into the areas which later became industrialized. Agriculture assists in industrialization in several ways: ( $\mathrm{I}$ ) Farm population is stable, in that farmers establish permanent homes and permanent communities. (2) Farming supplies a surplus popúlation which can migrate to nearby urban centers and provide labor for industry. (3) Since agricultural employment is seasonal, it affords an off-seasonal labor supply which encourages industries that offer dovetailing of employment to create offseasonal demands for labor. (4) Agriculturally supported towns and cities usually provide the early and frequently the most costly stages of community facilities, such as roads, highways, schools, health, and police protection, on which industrialization can build. (5) Finally, a highly concentrated agriculture generates the beginnings of mass markets around which industrialization can swing.

A second and equally essential outside force leading to industrialization is the ability of the region to innovate. The industrialization of a region popularly con- 
notes the establishment of competitive industries. It is believed that the region should have such a comparative advantage that industries will develop in the face of competition with older established firms. This, however, is not the usual pattern of industrialization. In most instances of regional economic expansion, the newly locating industries are new ones, such as was the case with the railroad equipment industry in the East, the automobile industry in the Midwest, and the airplane industry in the West. As technology changes, new regions, finding it difficult to compete with older ones with respect to well-established industries, are frequently quite receptive to the attendant innovations. Older regions, dependent upon established industries with their conventional patterns of production, subcontracting industries, credit, and marketing, tend to become somewhat rigid, and new concepts that do not conform with familiar ways may, therefore, be rejected. Attention, therefore, may possibly have been diverted in the assessment of economic expansion in the Pacific Northwest. The types of industry that are expected to develop may never appear. If industrialization occurs, it may well be spearheaded by industries that at present are in experimental stages. Such industries will grow and develop their own supporting industries in the process. What form they will take is impossible to predict.

Even if the possibility of industrial development based upon essentially new types of industry is granted, however, will it not occur with or without river basin development? Cannot innovations emerge which are independent of electric power as well as of the existence of supporting industries? When well-established modes of analysis are forsaken and reliance placed on speculation, anything is possible. No resources are so indispensable to development that development cannot possibly occur without them. Experience teaches us, however, to be cautious about economic projections. Arnold Toynbee warns that although. the greater the challenge, the greater the response, there are cases where the challenge may be too great. ${ }^{31}$

For several reasons, therefore, river basin development will increase the possibility of industrial expansion. In the first place, it usually provides more agricultural land, which, as has been seen above, still plays a significant role in economic expansion. Second, the greater the amount of resources that are made available, the greater will be the probability of economic expansion which directly or indirectly utilizes one or more of them as a vital raw material. The fact that abundant electricity led to the location of the Hanford and Arco atomic plants in the first instance may lead to the location in those regions of industries utilizing atomic energy or its by-products.

In conclusion, it may be stated that except for the economic expansion surrounding agriculture, very little is known about the type or the degree of economic expansion which will be induced by river basin development and the types of resources made available by it. It seems quite certain that industries that require cheap and abundant electricity will locate in the region. Beyond that, however, nothing is certain, except that the probabilities of industrial growth are enhanced. What effects such probable growth will have on the national economy will now be discussed.

312 Arnold J. Toynbee, A Study of History 274 et seq. (1934). 


\section{The Utility of Economic Expansion}

In most treatises, it is assumed that economic expansion is advantageous to the economy as a whole. Classical economic theory set out to prove, through the law of comparative costs, that industry would always become so distributed that trade between regions, as between countries, would be to the advantage of all trading areas. More commodities would be available than would be the case if trade were restricted, and a day's labor would inevitably exchange for more goods and services. Since, by definition, an economy affording its members more goods and services than another economy is a better economy, trade must inevitably lead to better economic conditions or to higher national social value. ${ }^{32}$

More recently, however, doubt has been expressed as to the net social gain derived from all trade. The argument proceeds that trade between areas leading to the exchange of complementary goods is beneficial, whereas trade between areas leading to the exchange of goods that are competitive is not. ${ }^{33}$ Complementary goods are commodities whose acquisition increases the utility of goods already possessed. For example, the acquisition of gasoline increases the utility of motor cars, the acquisition of cheap aluminum increases the utility of all products using aluminum. A competitive commodity, on the other hand, is one that acts as a substitute for another and, consequently, lowers the utility of the other commodity. Nylon, for example, lowered the utility of silk. The critical question, however, is whether or not the utility derived from securing a good substitute for silk was greater than the loss in utility of silk itself. If it was, there was a net social gain through the acquisition of nylon. The problem may be analyzed more effectively, then, by studying the effect of trade on the marginal efficiency of capital, rather than on the utility of the final product to consumers. If trade increases the value of capital goods and, consequently, induces greater investment, it is complementary. If, on the other hand, net investment decreases, such trade is competitive.

Without expounding further on their theoretical implications, these concepts may be applied to river basin development to determine the extent to which it adds to or detracts from the capital value of the national economy. This analysis is important for political reasons, for it is obvious that where public investment is required to develop river basins, such investment will enlist considerable political support if these developments will induce a considerable expansion in investments in older established areas; if, however, these developments will occasion a decrease in investments in older established areas, such investment will arouse much opposition.

With the exception of power developments, the initial impact of river basin de-

32 For a complete analysis of the measurement of the benefits of increasing trade, see JACOB VINER, Studies in the Theory of International Trade c. 9 (1937).

sa See JACOB VINER, THE Customs UNION Issue (1950); Smithies, European Unification and the Dollar Problem, 64 Q. I. Econ. 159 (1950); Meade, The Removal of Trade Barriers: the Regional Versus the Universal Approach, I8 Economics (n.s.) I84 (195I); Meyer, Complementarity and the Lowering of Tariffs, 46 AM. Econ. Rev. 323 (1956). 
velopment is to create competitive rather than complementary trade. Greater productivity of agricultural lands and the development of irrigation projects increase the production of food products which enter into national trade in competition with producing areas in other regions. The effect will, therefore, be to lower land values in these older areas and to decrease the utility of food products already produced there. Again, the cheap labor and favorable location of the Tennessee River Valley encouraged certain types of industries to move from the older established areas to the South, and, here, too, the effect was competitive, rather than complementary. In the Pacific Northwest, on the other hand, the development of electroprocess basic reduction plants, especially of aluminum, and the failure of metal products industries to develop resulted in an increase in investment of considerable magnitude in plants using aluminum in the Midwest and the East. Developments of this nature are truly complementary, and the East could well encourage future investments of this nature, since the immediate effect would be to increase the marginal efficiency of eastern capital.

The longer the period of time which elapses after economic expansion has commenced, however, the greater appears to be the tendency for all trade to become complementary. National industries which develop in a new area tend to be complementary from the outset; whereas competitive industries, such as agriculture, tend more and more to become market-oriented and to supply the needs of the local population.

Several tentative conclusions, therefore, can be submitted regarding the social utility derived from river basin development, as reflected in trade between the newly developed region and the nation at large.

I. The wider the variety of resources made available to private exploitation, the greater is the probability that economic expansion will reach advanced stages of industrialization and maturity.

2. Power resources tend to develop industries that are complementary rather than competitive to the economy as a whole, but power resources have little ability alone to induce economic expansion.

3. Agricultural developments have relatively strong growth-inducement potential, but they tend, in the early stages at least, to lead to competitive trade relationships with the rest of the country.

4. Regions that are in close proximity to highly industrialized areas and to mass markets will experience industrialization more rapidly than more remote regions, but their industrialization most likely will be competitive in the early stages of economic expansion.

5. Remote regions will tend to develop more slowly, but the type of economic expansion that they will experience will lead to trade that is complementary throughout.

6. All regions, regardless of their degree of competitiveness in the early stages of trade and-economic expansion, will ultimately become complementary ${ }^{34}$.

34 Meyer, supra note 33, at 333. 